\title{
THE GENUS PARADA HORVATH (HEMIPTERA: TINGIDAE) ${ }^{1}$
}

BY CARL J. DRAKE

Iowa State College, Ames

Horvath (Ark. Zool., 17A (24) :2-3, 1925) erected Parada as a subgenus of the genus Cysteochila Stal for the reception of Cysteochila (Parada) taeniophora. Seventeen years later, Drake (Iowa St. Coll. J. Sci., 17(1) :3-4, 1942) raised Parada to the generic level and described two new species and a new variety from Australia. The genus is not known to occur elsewhere.

The present paper describes three new species and one new variety of the genus Parada from Australia. I am indebted to Dr. Philip Darlington of the Museum of Comparative Zoology, Harvard University, for kindly loaning me the tingids, which he collected in Australia. The disposition of the types is given beneath the descriptions of the new species.

Genus Parada Horvath, 1925

Type, Cysteochila (Parada) taeniophora Horvath, 1925

Parada darlingtoni, new sp.

Head brown, with five testaceous spines; median spine short and blunt, the hind pair shorter in type than allotype, appressed. Eyes moderately large, black. Antennae long, rather slender, pale testaceous, the terminal segment almost totally black-fuscous; segment I short, stout, thicker and nearly twice as long as II; III very long, slenderest, smooth, scarcely more than four times as long as IV. Bucculae very wide, meeting in front, testaceous, areolate. Rostrum testaceous, extending to middle of metasternum; rostral laminae testaceous, areolate, subparallel, open behind.

Pronotum strongly convex, closely coarsely deeply pitted, black with hood, paranota, carinae and posterior projection testaceous, the posterior part of pronotum distinctly

${ }^{1}$ Published with a grant from the Museum of Comparative Zoology at Harvard College. 
areolate. Hood moderately large, inflated, not produced over base of head, highest near the center, there feebly higher than long, above narrowed from all sides to the peak; collar testaceous. Paranota moderately wide, mostly triseriate, almost completely reflexed inwardly on surface of pronotum, usually not quite touching pronotal surface at humeral angles. Median carina long, distinctly elevated, not areolate, extending from hood to apex of hind process. Lateral carinae a little sinuate, foliaceous on discal part of pronotum, there completely reflexed inwardly and biseriate in widest part, the space between upper edge and median carina about half as wide as width of lateral carina; lateral carinae on hind part ridge-like and not areolate.

Hemelytra strongly constricted beyond the middle, yellowish brown with four dark fuscous marks on the veins setting off discoidal area, the whitish patch near apex of costal area extending across subcostal into sutural area; costal area moderately wide, composed largely of one row (two at base) of fairly large, clear cells; subcostal area triseriate, the cells smaller than in costal area; discoidal area just reaching to middle of hemelytra, with outer boundary strongly sinuate, widest slightly beyond the middle, there six or seven cells deep; sutural area more widely reticulate, with cells infuscate, with a pale patch near apex; areolae of subcostal, discoidal and sutural area opaque. Wings clouded with dark fuscous, not as long as hemelytra. Hypocostal vein uniseriate. Body beneath black-fuscous, the median part of venter sometimes brownish. Legs testaceous, the tips of tibiae and tarsi reddish brown to fuscous.

Length, 3.50-3.75 mm.; width, $1.20-1.38 \mathrm{~mm}$.

Type (male), National Park, Queensland, McPherson Range, Australia, Alt. 3000-4000 feet, May 11, 1932, collected by Dr. P. J. Darlington, in collection of Museum of Comparative Zoology (Harvard). Allotype, female, taken with type.

This species may be separated at once from other members of the genus by the narrower, biseriate lateral carinae of pronotum. The hood is about the same size as in $P$. popla Drake, but the antennae and legs are distinctly longer. $P$. 
absona has a distinctly smaller hood, and wider foliaceous part of lateral carina.

\section{Parada hackeri, new sp.}

Moderately elongate, small, oblong. Head flat above, reddish brown with five testaceous spines; median spine short, appressed; anterior pair longer, porrect, with their tips touching; hind pair very long, appressed. Antennae moderately long, moderately stout, indistinctly pilose, testaceous with terminal segment dark fuscous; segment I short, a little stouter and not quite twice as long as II; III slightly more than twice as long as IV; IV thicker in widest part, narrowed at base and apex, clothed with short hairs. Bucculae wide, testaceous, areolate, closed in front. Rostrum testaceous, extending a little beyond middle of mesosternum; rostral laminae testaceous, areolate, open behind. Entire body beneath dark reddish brown.

Pronotum slightly convex, closely deeply pitted, reddish brown with carinae, paranota, hood and posterior projection of pronotum testaceous; hood moderately large, only slightly raised, about one cell high, flat above, not produced anteriorly. Paranota moderately wide, mostly triseriate, almost totally reflexed inwardly, not quite resting on dorsal surface of pronotum at humeral angles. Lateral carinae long, foliaceous on convex part of pronotum, there reflexed inwardly and triseriate, continuing on hind part of pronotum as a raised vein, which terminates a little before the apex. Median carina profound, not areolate. Hind process of pronotum about as widely areolate as discoidal area.

Hemelytra slightly constricted a little beyond middle, brownish; costal area narrow, uniseriate, the cells small and mostly longer than wide, testaceous with some scattered dark fuscous spots on outer vein; discoidal area wider, biseriate, with larger cells; discoidal area large, extending considerably beyond middle of hemelytra, set off from other areas by raised veins (especially inner boundary), narrowed at both base and apex, slightly elevated at apex and at dark spot on outer boundary, widest near middle, there five cells deep, the outer marginal vein only slightly sinuate; sutural area more widely areolate, with veinlets yellowish brown and areolae dark fuscous. Wings black-fus- 
cous, almost as long as hemelytra. Legs rather short, testaceous.

Length, $3.00 \mathrm{~mm}$; width, $1.00 \mathrm{~mm}$.

Type (male), Mt. Gipps, Queensland, Australia, April 20, 1930, H. H. Hacker, in collection of C. J. Drake.

This is the smallest described species in the genus. It can be distinguished from its congeners by the non-inflated hood, narrow costal area, feebly convex pronotum and flat dorsal aspect of head as well as smaller size of body.

Parada absona, new sp.

Oblong, testaceous, with the last antennal segment, and anterior and discal parts of pronotum black, also a long mark on raised boundary veins (beyond middle) between discoidal and subcostal areas, a small spot beyond apex of discoidal area and a subapical spot in discoidal area dark fuscous. Hood, collar, carinae, paranota and posterior part of pronotum testaceous.

Head black, with five testaceous spines. Antennae long, indistinctly pilose; segment I short, stouter and a little longer than II; III three times as long as IV. Rostrum testaceous, extending a little beyond mesosternum. Rostral laminae areolate, testaceous, open behind. Bucculae, wide, testaceous, closed in front. Legs moderately long, testaceous.

Pronotum strongly convex, deeply coarsely closely pitted, tricarinate; hood rather small, inflated, not very high, bell-shaped, not extending posteriorly over convex part of pronotum; paranota moderately wide, triseriate, almost completely reflexed, not quite touching surface of pronotum opposite humeral angles. Median carina profound, moderately raised, without distinct areolae. Lateral carinae sinuate, moderately wide and foliaceous on pronotum proper, there completely reflexed inwardly, each continued as a raised nerve on hind process, the space between upper edge of foliaceous part and median carina about half as wide as carina.

Hemelytra moderately constricted beyond the middle; costal area moderately wide, mostly uniseriate, biseriate for a short distance at base, the cells moderately large and hyaline; subcostal area a little wider, biseriate; discoidal area long, about three-fourths as long as hemelytra, with 
outer boundary only a little sinuate, widest beyond middle, there six cells deep, narrowed at both base and apex; sutural area with cells a little larger; hypocostal vein uniseriate. Wings deeply clouded with dark fuscous, not as long as hemelytra.

Type (male), Lake Barrine, Queensland, Australia, El. 2900 feet, April 19, 1932, P. J. Darlington, in Museum Comparative Zoology (Harvard). Allotype and 4 paratypes, taken with type.

This species is most closely allied to $P$. torta Drake, but is easily separated from it by the longer body, much shorter and smaller hood, longer carinae and shape of discoidal area. The hood of $P$. torta is much larger and projects backwards over anterior part of convex pronotum.

Parada torta Drake

Parada torta Drake, Iowa St. Coll. J. Sci., 17 (1) :4, 1942.

Six specimens, Mt. Wilson, Blue Mts., N. S. W., Australia, El. 8500 feet, Jan., 1932, P. J. Darlington. Known heretofore only from the type locality, Mt. Gipps, Queensland.

\section{Parada torta pulla, new var.}

Separated from typical form by the black head, pronotum, hood, paranota, carinae and discoidal and large part of subcostal areas of hemelytra. Size same as typical form, $3.00 \mathrm{~mm}$. long.

Type (female), Mt. Wilson, Blue Ridge, El. 8500 feet, N. S. W., Australia, P. J. Darlington, in Museum Comparative Zoology (Harvard).

\section{Parada popla Drake}

Parada popla Drake, Iowa St. Coll. J. Sci., 17 (1) :3, 1942.

Numerous specimens, National Park, McPherson Ridge, Queensland, Elevation 3,000-4,000 feet, March 11, 1932, P. J. Darlington.

\section{Parada taeniophora Horvath}

Cysteochila (Parada) taeniophora Horvath, Ark. Zool $17 \mathrm{~A}(24): 2$, p. 2.1925.

Several specimens, Mt. Surgeon, N. Q., Australia, El. 3,500-4,000 ft., July 28, 1932; Lake Barrine, Atherton Tab., El., 2,800 feet, April 28, 1932, all by P. J. Darlington. 

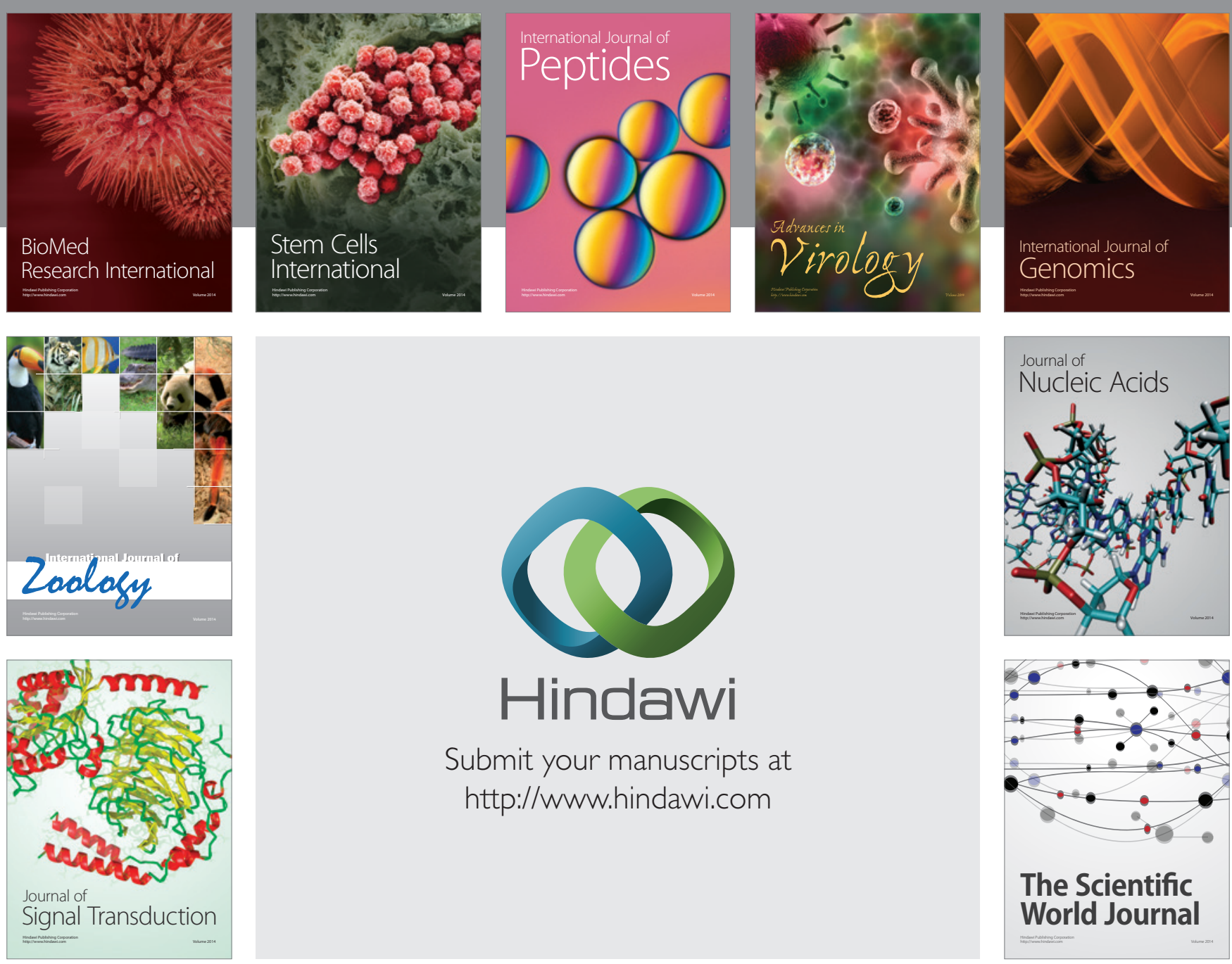

Submit your manuscripts at

http://www.hindawi.com
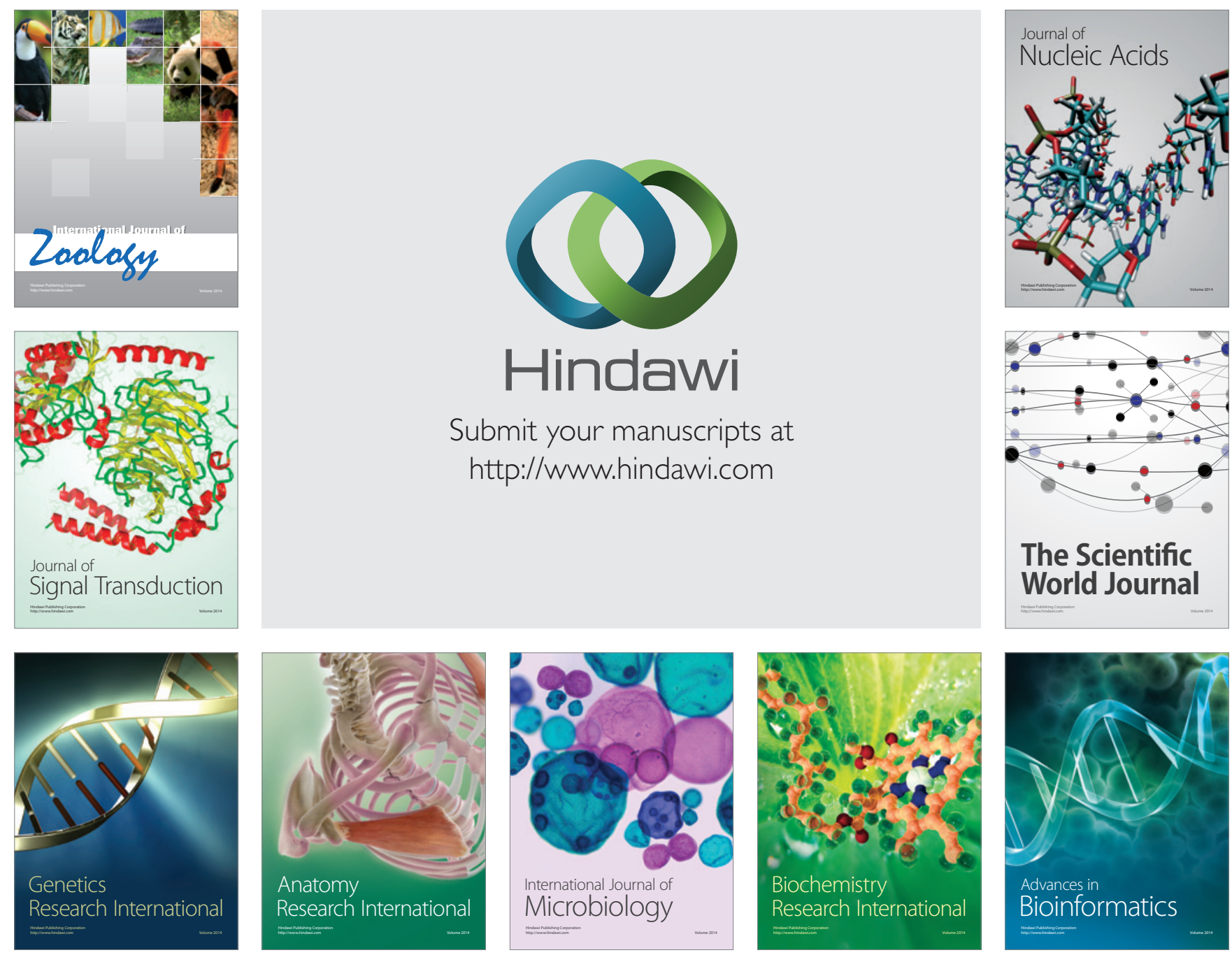

The Scientific World Journal
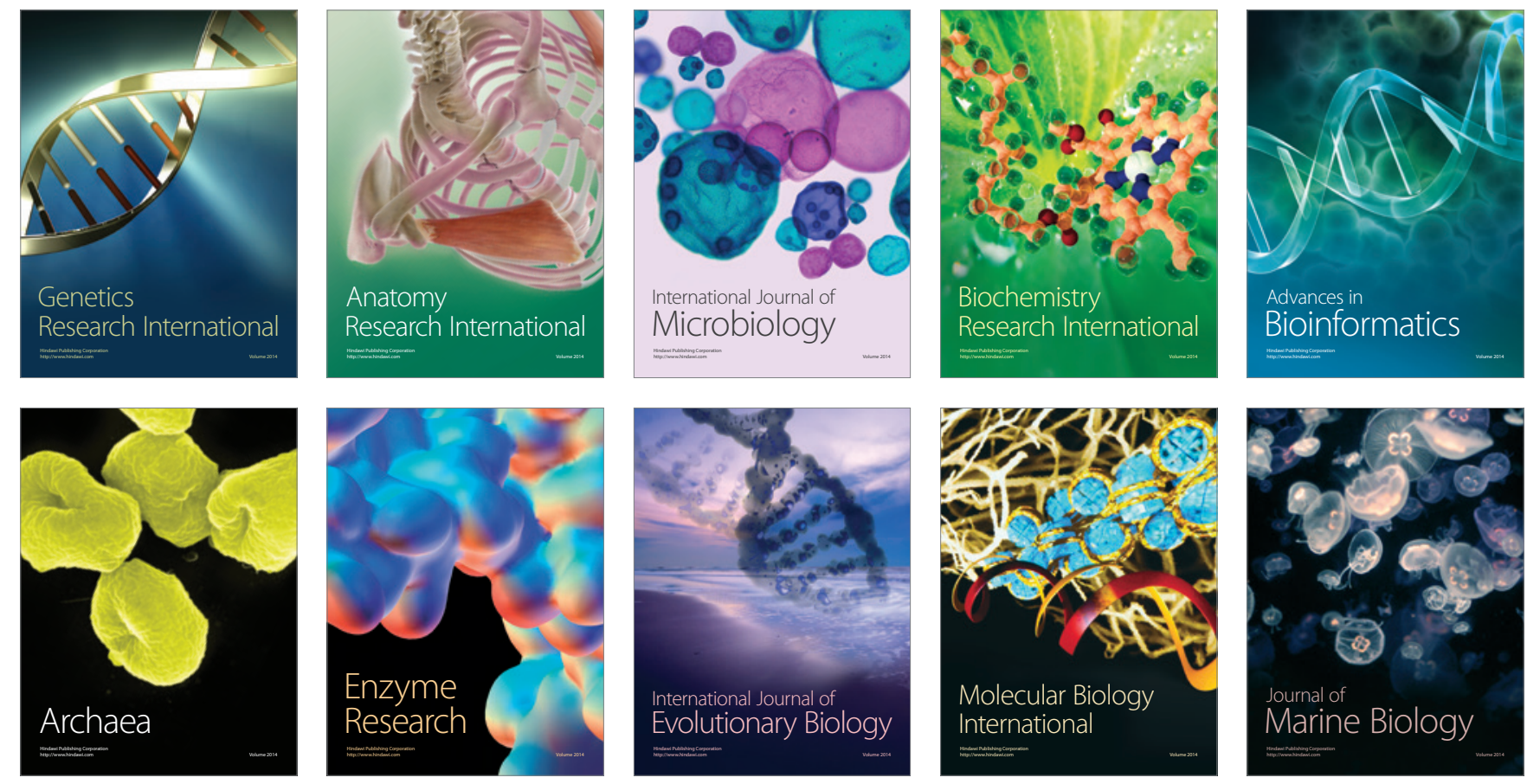